\title{
Nuclear Imaging for the Diagnosis of Cardiac Amyloidosis in 2021
}

\author{
Weijia Li ${ }^{1}$,* , Dipan Uppal ${ }^{1}$, Yu Chiang Wang ${ }^{1}{ }^{\oplus}$, Xiaobo Xu ${ }^{1}$, Damianos G. Kokkinidis ${ }^{2}$, Mark I. Travin ${ }^{3}$ \\ and James M. Tauras ${ }^{4}$
}

1 Department of Medicine, Jacobi Medical Center, Albert Einstein College of Medicine, 1400 Pelham Parkway South, Bronx, NY 10461, USA; uppald@nychhc.org (D.U.); wangy19@nychhc.org (Y.C.W.); xux7@nychhc.org (X.X.)

2 Section of Cardiovascular Medicine, Yale University School of Medicine, 333 Cedar Street, New Haven, CT 06510, USA; damianos.kokkinidis@yale.edu

3 Department of Radiology, Division of Nuclear Medicine, Montefiore Medical Center, Albert Einstein College of Medicine, 111 East 210th Street, Bronx, NY 10467, USA; mtravin@montefiore.org

4 Department of Medicine, Division of Cardiology, Montefiore Medical Center, Albert Einstein College of Medicine, 111 East 210th Street, Bronx, NY 10467, USA; jtauras@montefiore.org

* Correspondence: liw11@nychhc.org

check for updates

Citation: Li, W.; Uppal, D.; Wang, Y.C.; Xu, X.; Kokkinidis, D.G.; Travin, M.I.; Tauras, J.M. Nuclear Imaging for the Diagnosis of Cardiac Amyloidosis in 2021. Diagnostics 2021, 11, 996. https://doi.org/10.3390/ diagnostics11060996

Academic Editor: Michael Henein

Received: 16 May 2021

Accepted: 27 May 2021

Published: 30 May 2021

Publisher's Note: MDPI stays neutral with regard to jurisdictional claims in published maps and institutional affiliations.

Copyright: (c) 2021 by the authors. Licensee MDPI, Basel, Switzerland. This article is an open access article distributed under the terms and conditions of the Creative Commons Attribution (CC BY) license (https:/ / creativecommons.org/licenses/by/ $4.0 /)$.

\begin{abstract}
Cardiac amyloidosis is caused by the deposition of misfolded protein fibrils into the extracellular space of the heart. The diagnosis of cardiac amyloidosis remains challenging because of the heterogeneous manifestations of the disease. There are many different types of amyloidosis with light-chain (AL) amyloidosis and transthyretin (ATTR) amyloidosis being the most common types of cardiac amyloidosis. Endomyocardial biopsy is considered the gold standard for diagnosing cardiac amyloidosis and differentiating amyloid subtypes, but its use is limited because of the invasive nature of the procedure, with risks for complications and the need for specialized training and centers to perform the procedure. Radionuclide cardiac imaging has recently become the most commonly performed test for the diagnosis of ATTR amyloidosis but is of limited value for the diagnosis of AL amyloidosis. Positron emission tomography has been increasingly used for the diagnosis of cardiac amyloidosis and its applications are expected to expand in the future. Imaging protocols are under refinement to achieve better quantification of the disease burden and prediction of prognosis.
\end{abstract}

Keywords: cardiac amyloidosis; cardiac scintigraphy; positron emission tomography

\section{Introduction}

Systemic amyloidosis is a multisystem disorder characterized by the formation and deposition of mis-folded protein fibrils which can result in multi-organ failure and death [1,2]. This condition is associated with significant disease burden with increasing incidence and prevalence worldwide over the past decades [3-5]. Studies have shown that at least 20 out of one million UK residents are estimated to have systemic amyloidosis with $65 \%$ being light-chain (AL) amyloidosis. The prevalence of wild type ATTR amyloidosis is estimated to be $10-25 \%$ in people over the age of 80 [6-9].

Cardiac amyloidosis is defined as a group of disorders that involve the deposition of amyloid protein in the cardiac tissue, leading to myocardial dysfunction [10]. Due to the increasing awareness of the disease, improved life expectancy, and advancements in diagnostic pathways, cardiac amyloidosis is currently diagnosed more frequently than in the past, with AL and ATTR amyloidosis being the most common types [3]. One populationbased study focusing on Medicare beneficiaries in the United States revealed that between 2000 and 2012 the prevalence of cardiac amyloidosis increased from 8 to 17 cases per 100,000 person-year and the incidence increased from 18 to 55 cases per 100,000 personyear [11]. It is estimated that by 2050 there will be almost 25 million cases of wild-type ATTR globally $[12,13]$. 
AL amyloidosis is caused by the deposition of fragments of immunoglobulin and is associated with plasmacyte disorders such as multiple myeloma [14]. On the other hand, ATTR amyloidosis results from misfolded transthyretin, which normally functions as a transporter for thyroid hormone and retinol-binding protein [15]. ATTR amyloidosis can be further divided into wild-type which develops as people age and a hereditary form caused by inherited mutations [16,17].

AL cardiac amyloidosis and ATTR cardiac amyloidosis are clinically distinctive diseases and the diagnosis and differentiation are of vital importance, mainly because of the drastically different treatment strategies [18]. For example, the development of tafamidis, which acts on the rate-limiting step of the amyloidogenic process by binding to transthyretin, stabilizing the tetramer and slowing the dissociation into monomers, has revolutionized the therapeutic landscape for ATTR amyloidosis. On the other hand, the management for AL cardiac amyloidosis focuses on the control of the underlying plasmacyte disorder such as autologous stem cell transplantation and bortezomib-based treatment [19]. Thus, the early and accurate diagnosis of cardiac amyloidosis is essential [20]. Endomyocardial biopsy (EMB) is considered the gold standard for the diagnosis of cardiac amyloidosis when combined with mass spectrometry to ascertain specific subtypes [21,22]. However, given the heterogeneity of cardiac amyloidosis, EMB may fail to diagnose the disease. Additionally, it is an invasive procedure by nature and thus can lead to serious complications such as right ventricle perforation, cardiac tamponade, and even death $[23,24]$.

Nuclear imaging as an alternative diagnostic approach has become more popular among clinicians who suspect cardiac amyloidosis in their patients. In addition, compared to other imaging modalities such as echocardiogram and cardiac magnetic resonance imaging (CMR), nuclear imaging is the only available non-invasive method that can accurately distinguish ATTR amyloidosis from AL cardiac amyloidosis within the appropriate clinical settings [25]. Nuclear imaging has been viewed as an essential part of the diagnosis of cardiac amyloidosis and has been included in the multi-society consensus statement published in 2019 [26,27]. With this review article, we aim to summarize and discuss the current landscape of nuclear imaging for the diagnosis of cardiac amyloidosis, recent advancements and expected future changes in the field and how nuclear imaging can help cardiovascular clinicians diagnose cardiac amyloidosis.

\section{Imaging Techniques and Radiotracers}

Nuclear imaging for cardiac amyloidosis includes cardiac scintigraphy which adopts radiotracers from bone scintigraphy and the technique of Positron Emission Tomography (PET) using targeted tracers for amyloid specific proteins (Figure 1). Nuclear imaging can offer direct visualization of disease activity and semi-quantification of the amyloid burden by calculating the ratio between concentration of the radiotracer in a specific volume of tissue and the concentration if the radiotracers are uniformly distributed. The ratio is also known as Standardized Uptake Value (SUV) [28]. Retention index (RI), calculated to assess the retention of radiotracers in myocardium over certain time interval, can be another important method measuring amyloid deposition quantitatively in PET imaging [29-31]. 

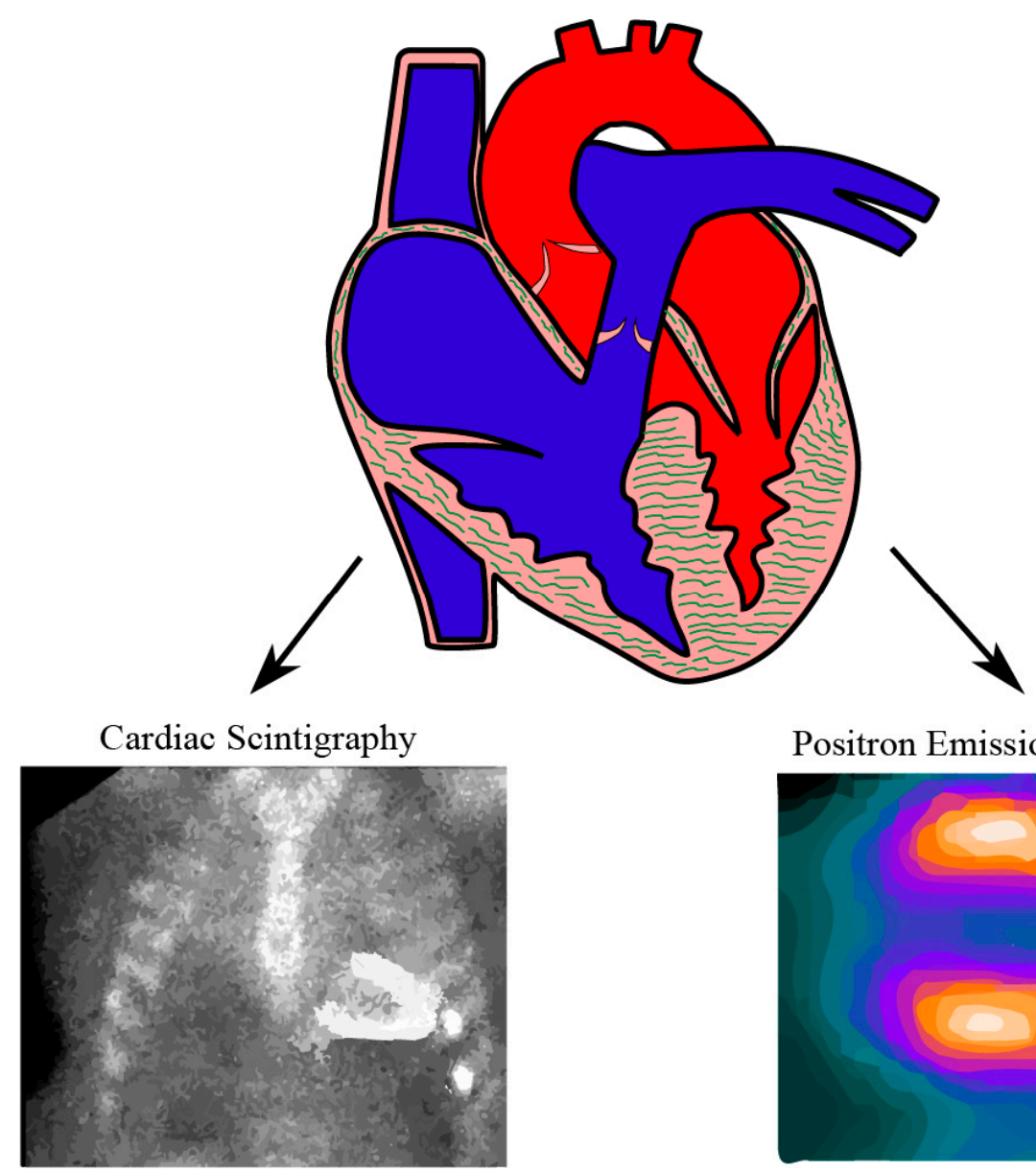

Positron Emission Tomography

Figure 1. Illustration of nuclear imaging modalities for cardiac amyloidosis.

\section{Cardiac Scintigraphy}

Technetium (Tc)-labeled radiotracers from phosphate derivatives which are common bone scan agents have been investigated for the diagnosis of amyloidosis since the 1970s [32]. Cardiac scintigraphy utilizing those radiotracers has become more popular and widely used in clinical practice to assist the diagnosis of cardiac amyloidosis. A large-sized multi-center study including 1217 patients with suspected cardiac amyloidosis supported that cardiac scintigraphy with ${ }^{99 \mathrm{~m}} \mathrm{Tc}$-diphosphono-1,2-propanodicarboxylic acid ( $\left.{ }^{99 \mathrm{~m}} \mathrm{Tc}-\mathrm{DPD}\right),{ }^{99 \mathrm{~m}} \mathrm{Tc}-$ pyrophosphate $\left({ }^{99 \mathrm{~m}} \mathrm{Tc}-\mathrm{PYP}\right)$, or ${ }^{99 \mathrm{~m}} \mathrm{Tc}-$ hydroxymethylene diphosphonate $\left.{ }^{99 \mathrm{~m}} \mathrm{Tc}-\mathrm{HMDP}\right)$ had a $100 \%$ specificity and positive predictive value for ATTR cardiac amyloidosis if there are combined findings of grade 2 or 3 myocardial radiotracer uptake on cardiac scintigraphy and the absence of monoclonal protein in serum or urine [33]. Systematic review also confirmed the accuracy of scintigraphy diagnosing ATTR cardiac amyloidosis with both sensitivity and specificity above 90\% [34]. Although it remains unclear how those bone-seeking agents can differentiate the types of amyloidosis, theories have postulated that the higher calcium containing compounds in ATTR cardiac amyloidosis, the unique characteristics of amyloidogenic fibrils, and the more indolent clinical course of ATTR amyloidosis allowing larger amount of amyloid protein to accumulate before the onset of symptoms might play a role [35]. However, the results of cardiac scintigraphy can be affected by multiple factors such as rib fracture and valvular/annular calcifications [36]. Single-Photon Emission Computed Tomography (SPECT) technique can add a three-dimensional visualization to planar scintigraphy as well as more detailed and accurate assessment of radiotracer uptake in the myocardium wall as opposed to the blood pool [37]. Currently, ${ }^{99 \mathrm{~m}} \mathrm{Tc}-\mathrm{DPD}$ and ${ }^{99 \mathrm{~m}} \mathrm{Tc}-\mathrm{PYP}$ are the two most commonly used and studied radiotracers for the diagnosis of ATTR cardiac amyloidosis. 


\section{4. ${ }^{99 \mathrm{~m}} \mathrm{Tc}-3,3-d i p h o s p h o n o-1,2-$-propanodicarboxylic Acid $\left({ }^{99 \mathrm{~m}} \mathrm{Tc}-\mathrm{DPD}\right)$ Scintigraphy}

${ }^{99 \mathrm{~m}} \mathrm{Tc}-\mathrm{DPD}$ scintigraphy is usually performed as a whole-body planar imaging three hours after the injection of ${ }^{99 \mathrm{~m}} \mathrm{Tc}-\mathrm{DPD}$ radiotracer which can be followed by SPECT and non-contrast $\mathrm{CT}$ as adjuncts. ${ }^{99 \mathrm{~m}} \mathrm{Tc}-\mathrm{DPD}$ scintigraphy has high diagnostic accuracy for ATTR amyloidosis, especially when using the Perugini visual score. According to the Perugini visual score, the degree of radiotracer uptake is visually graded by comparing the radiotracer activity in the heart with its activity in the bones. Grade 0 means no cardiac uptake of radiotracer; grade 1 means that cardiac uptake is mild and less than skeletal uptake; grade 2 means that cardiac uptake is moderate and equals skeletal uptake; grade 3 means cardiac uptake is high and stronger than skeletal uptake. Grade 2 and above are considered as positive scan [38]. However, this protocol can lead to false positive results in patients with AL cardiac amyloidosis [33]. Therefore, AL cardiac amyloidosis needs to be ruled out first with serum free light chains, serum protein electrophoresis, and urine protein electrophoresis before interpreting the results of cardiac scintigraphy. As the visual scoring system highly depends on reader expertise, it performed poorly when assessing the degree of amyloid burden [39]. In addition, Perugini visual score has not been found to have any prognostic significance in the overall survival for patients with cardiac amyloidosis [40].

Researchers have attempted to increase the diagnostic accuracy of ${ }^{99 \mathrm{~m}} \mathrm{Tc}-\mathrm{DPD}$ scintigraphy and quantitatively assess amyloid burden by calculating the ratio between retention of radiotracer in the heart and retention of radiotracer in other body parts. Heart/wholebody ratio $(\mathrm{H} / \mathrm{WB})$, heart/pelvis ratio and heart/contralateral lung ratios $(\mathrm{H} / \mathrm{CL})$ are commonly used in clinical studies [41]. ATTR amyloidosis was found to have a higher $\mathrm{H} / \mathrm{WB}$ ratio than AL amyloidosis. A study from Australia which enrolled biopsy-proven AL and ATTR cardiac amyloidosis has proposed a cut-off of H/WB ratio $>0.091$ with sensitivity of $92 \%$ and specificity of $88 \%$ for the diagnosis of ATTR amyloidosis [42]. Additionally, an increasing $\mathrm{H} / \mathrm{WB}$ ratio has been shown to correlate with major adverse cardiac events in patients with hereditary ATTR cardiac amyloidosis [43]. Interestingly, researchers also found that ${ }^{99 \mathrm{~m}} \mathrm{Tc}-\mathrm{DPD}$ scintigraphy might have a role in the diagnosis of extracardiac AL amyloidosis when cardiac uptake is absent [44].

SPECT/CT has been developed to assist quantification in ${ }^{99} \mathrm{~m}$ Tc-DPD Scintigraphy by acquiring peak Standard Uptake Values (SUVs) in the myocardium and offering threedimensional assessment [45]. The cardiac peak SUV can be further normalized with the peak SUV on the bone or soft tissue as SUV retention index [46]. Studies have shown that cardiac SUV and SUV retention index are correlated well with Perugini visual scores and a peak SUV cut-off of 3.1 can separate patients with Perugini grade 2 and 3 clearly from those with Perugini grade 0 and 1 [47]. A recent study has found that the amyloid load in ${ }^{99} \mathrm{~m}$ Tc-DPD SPECT/CT has correlated well with strain values in echocardiography and biomarkers such as troponin and NT-proBNP (B-type Natriuretic Peptide) [48]. However, SPECT/CT was still unable to differentiate between patients with Perugini grade 2 and 3 , which suggests that quantification of amyloid burden by ${ }^{99 \mathrm{~m}} \mathrm{Tc}-\mathrm{DPD}$ SPECT /CT needs further improvement [39].

\section{5. ${ }^{99 \mathrm{~m}}$ Tc-Pyrophosphate ( $\left.{ }^{99 \mathrm{~m}} \mathrm{Tc}-\mathrm{PYP}\right)$ Scintigraphy}

Although promising, ${ }^{99} \mathrm{~m}$ Tc-DPD is not approved for use by the Food and Drug Administration (FDA) in the United States. Hence, ${ }^{99 \mathrm{~m}} \mathrm{Tc}-$ pyrophosphate $\left({ }^{99 \mathrm{~m}} \mathrm{Tc}-\mathrm{PYP}\right)$ is the only FDA-approved radiotracer in the US to diagnose cardiac amyloidosis [49]. Clinicians usually obtain anterior, lateral and left anterior oblique planar views as well as SPECT imaging following injection of ${ }^{99 \mathrm{~m}} \mathrm{Tc}-\mathrm{PYP}$ [50]. The degree of myocardial tracer uptake is graded using the semi-quantitative Perugini visual score and quantitative analysis by obtaining radiotracer activity within a region of interest (ROI) drawn over the heart corrected and its activity in the contralateral side of ROI to calculate a heart-to-contralateral $(\mathrm{H} / \mathrm{CL})$ ratio [51]. Unlike the 3-h protocol which is required in ${ }^{99 \mathrm{~m}} \mathrm{Tc}-\mathrm{DPD}$ scintigraphy, it has been found that a 1-h protocol in ${ }^{99 \mathrm{~m}} \mathrm{Tc}-\mathrm{PYP}$ imaging is comparable to the 3 -h protocol for the diagnosis of ATTR cardiac amyloidosis. This translates to a $98 \%$ sensitivity and a $96 \%$ 
specificity of planar imaging and SPECT, identical between the 1-h and 3-h protocols [52]. The 1-h protocol reduces cost and time without compromising the diagnostic accuracy of the test and thus it is widely used.

Bokhari et al. found that subjects with ATTR cardiac amyloidosis had a significantly higher cardiac visual score $(p<0.0001)$ as well as higher H/CL ratio $(p<0.00001)$ than AL amyloidosis and they concluded that using a H/CL ratio of $\geq 1.5$, which is consistent with intensely diffused myocardial tracer retention, had a $97 \%$ sensitivity and $100 \%$ specificity $(p<0.0001)$ for identifying ATTR cardiac amyloidosis [35]. In a multicenter study which enrolled 171 participants, ${ }^{99 m}$ Tc-PYP scan demonstrated an overall $91 \%$ sensitivity and $92 \%$ specificity for detecting ATTR cardiac amyloidosis with area under the curve of $0.960(95 \%$ CI, 0.930-0.981) [53]. It has also been noted that an H/CL ratio $\geq 1.6$ predicts lower 5-year survival compared with group of patients with an $\mathrm{H} / \mathrm{CL}$ ratio $\leq 1.6$ (log-rank $p=0.02)$ [53]. Despite the high accuracy of the ${ }^{99 \mathrm{~m}} \mathrm{Tc}-\mathrm{PYP}$ scan visual score and H/CL ratio, the addition of SPECT is still necessary to rule out misclassified cases and distinguish myocardial activity from blood pool uptake [54]. A recent study showed that combining ${ }^{99 \mathrm{~m}} \mathrm{Tc}-\mathrm{PYP}$ and Thallium (Tl)-201 may improve diagnostic accuracy of both visual differentiation and H/CL semi-quantification for ATTR amyloidosis [55]. In addition, an integrated approach of utilizing both high sensitivity cardiac troponin $\mathrm{T}$ and ${ }^{99 \mathrm{~m}} \mathrm{Tc}-\mathrm{PYP}$ scintigraphy can significantly increase diagnostic yield of wild-type ATTR cardiac amyloidosis [56]. A series of studies of ${ }^{99 \mathrm{~m}} \mathrm{Tc}-\mathrm{DPD}$ and ${ }^{99 \mathrm{~m}} \mathrm{Tc}-\mathrm{PYP}$ scintigraphy published from 2020 to 2021 are listed in Table 1.

Table 1. Summary of a series of published studies of nuclear imaging in cardiac amyloidosis from 2020 to 2021.

\begin{tabular}{|c|c|c|c|}
\hline First Author & Publication Year & Radiotracer & Method \\
\hline Caobelli et al. [39] & 2020 & ${ }^{99 m}$ Tc-DPD & $\begin{array}{c}\text { Retrospective single-center } \\
\text { study including } 13 \text { patients } \\
\text { with } 8 \text { ATTR cardiac } \\
\text { amyloidosis and } 5 \text { not. }\end{array}$ \\
\hline
\end{tabular}

Scully et al. [46] ${ }^{99 \mathrm{~m}}$ Tc-DPD

Wollenweber et al. [47]

2020 ${ }^{99 m}$ Tc-DPD

Löfbacka et al. [48] 2020 ${ }^{99 m}$ Tc-DPD
Single-center, retrospective study of 100 DPD scan (40 were Perugini grade 0,12 were grade 1,41 were grade 2 , and 7 were grade 3 ).
Myocardial SUV $\mathrm{Sax}_{\max }$ and $\mathrm{SUV}_{\text {peak }}$ showed strong correlation with Perugini score but a great degree of overlap between patients in Perugini score 2 and 3.

SUV retention index which is calculated as: ((Cardiac

$\mathrm{SUV}_{\text {peak }} /$ Vertebral SUV $\left.\mathrm{Seak}_{\text {pe }}\right)$ $\times$ paraspinal muscle

$\left.\mathrm{SUV}_{\text {peak }}\right)$ increased across all Perugini grades. Cardiac

$\mathrm{SUV}_{\text {peak }}$ and SUV retention index had excellent

diagnostic accuracy with the area under the curve being 0.999 .

Patients with Perugini grade 2 and 3 can be clearly separated from those with Perugini grade 0 and 1 with a SUV $V_{\text {peak }}$ cut-off of 3.1.

Statistically significant correlation between DPD uptake and all echocardiographic strain parameters in all regions, as well as the biomarkers of troponin and logarithmic NT-proBNP. 
Table 1. Cont.

\begin{tabular}{|c|c|c|c|c|}
\hline First Author & Publication Year & Radiotracer & Method & Results \\
\hline Masri et al. [52] & 2020 & ${ }^{99 m}$ Tc-PYP & $\begin{array}{c}233 \text { patients with suspected } \\
\text { ATTR cardiac amyloidosis } \\
\text { underwent planar and } \\
\text { SPECT imaging at } 1 \text { and } 3 \\
\text { hours with a positive scan } \\
\text { considered as visual grades } \\
\geq 2 \text { and heart to contralateral } \\
\text { ratios } \geq 1.5\end{array}$ & $\begin{array}{l}\text { 1-hour and 3-hour protocols } \\
\text { have identical SPECT results. } \\
\text { Planar imaging at } 1 \text { hour had } \\
98 \% \text { sensitivity and } 96 \% \\
\text { specificity. }\end{array}$ \\
\hline Asif et al. [54] & 2020 & ${ }^{99 m}$ Tc-PYP & $\begin{array}{l}\text { 99m Tc-PYP scintigraphy was } \\
\text { performed including } 1 \text {-hour } \\
\text { planar imaging assessing } \\
\text { visual score as well as H/CL } \\
\text { ratio and SPECT }\end{array}$ & $\begin{array}{l}\text { Visual score had a diagnostic } \\
\text { accuracy of } 98 \% \text { for ATTR } \\
\text { cardiac amyloidosis but } \\
\text { addition of H/CL ratio } \\
\text { reduced the accuracy. SPECT } \\
\text { is necessary to perform to } \\
\text { prevent misdiagnoses. }\end{array}$ \\
\hline $\begin{array}{c}\text { Tamarappoo et al. } \\
{[55]}\end{array}$ & 2020 & ${ }^{99 m}$ Tc-PYP/Tl-201 & $\begin{array}{c}\text { Dual isotope of } \\
\text { 99m Tc-PYP/Tl-201 SPECT } \\
\text { was performed in } 112 \\
\text { patients suspicious of cardiac } \\
\text { amyloidosis (39 ATTR, } 26 \\
\text { AL, } 47 \text { no amyloidosis) and } \\
\text { compared with single } \\
\text { isotope. H/CL ratio } \\
\text { was calculated. }\end{array}$ & $\begin{array}{l}\text { Interobserver agreement of } \\
\text { visual assessment was better } \\
\text { with dual-isotope SPECT. } \\
\text { Area under the curve for } \\
\text { ATTR cardiac amyloidosis by } \\
\text { visual assessment and H/CL } \\
\text { ratio were higher with } \\
\text { dual-isotope SPECT than } \\
\text { single-isotope SPECT. }\end{array}$ \\
\hline Ochi et al. [56] & 2020 & ${ }^{99 \mathrm{~m}}$ Tc-PYP & $\begin{array}{l}39 \text { patients with wild-type } \\
\text { ATTR cardiac amyloidosis } \\
\text { with } 8 \text { patients in group A } \\
\text { who were diagnosed before } \\
\text { the introduction of hs-cTnT } \\
\text { and }{ }^{99 \mathrm{~m}} \text { Tc-PYP scintigraphy } \\
\text { and } 31 \text { patients in group B } \\
\text { who were diagnosed after } \\
\text { the introduction of the } \\
\text { two tools. }\end{array}$ & $\begin{array}{l}\text { Increased diagnostic yield in } \\
\text { patients who used the } \\
\text { combined approach using } \\
\text { hs-cTnT and } \\
{ }^{99 \mathrm{~m}} \text { Tc-PYP scintigraphy. }\end{array}$ \\
\hline Takasone et al. [57] & 2020 & ${ }^{99 \mathrm{~m}} \mathrm{Tc}-\mathrm{PYP},{ }^{11} \mathrm{C}-\mathrm{PiB}$ & $\begin{array}{l}17 \text { patients with AL cardiac } \\
\text { amyloidosis, } 22 \text { patients with } \\
\text { hereditary ATTR cardiac } \\
\text { amyloidosis, and } 8 \text { patients } \\
\text { with wild-type ATTR cardiac } \\
\text { amyloidosis underwent both } \\
{ }^{11} \text { C-PiB PET imaging and } \\
\text { 99m Tc-PYP scintigraphy. }\end{array}$ & $\begin{array}{c}\text { All patients with cardiac } \\
\text { amyloidosis are detectable } \\
\text { by }{ }^{99 \mathrm{~m}} \mathrm{Tc}-\mathrm{PYP} \text { or }{ }^{11} \mathrm{C}-\mathrm{PiB} \text { PET } \\
\text { imaging. The combination of } \\
\text { positive }{ }^{11} \mathrm{C}-\mathrm{PiB} \text { PET and } \\
\text { negative }{ }^{99 \mathrm{~m}} \mathrm{Tc}-\mathrm{PYP} \text { was } \\
\text { observed in all AL cardiac } \\
\text { amyloidosis and early onset } \\
\text { V30M hereditary ATTR } \\
\text { cardiac amyloidosis, while } \\
\text { the combination of positive } \\
{ }^{99 \mathrm{~m}} \text { Tc-PYP and negative } \\
{ }^{11} \mathrm{C}-\mathrm{PiB} \text { PET was consistent } \\
\text { in all wild-type ATTR } \\
\text { cardiac amyloidosis, as well } \\
\text { as the late-onset V30M and } \\
\text { non-V30M hereditary ATTR } \\
\text { cardiac amyloidosis. }\end{array}$ \\
\hline
\end{tabular}


Table 1. Cont.

\begin{tabular}{|c|c|c|c|}
\hline First Author & Publication Year & Radiotracer & Method \\
\hline $\begin{array}{l}\text { Rosengren et al. } \\
{[58]}\end{array}$ & 2020 & ${ }^{11} \mathrm{C}-\mathrm{PiB}$ & $\begin{array}{l}\text { A dual-center study included } \\
51 \text { subjects with } 36 \text { patients } \\
\text { with known cardiac } \\
\text { amyloidosis and increased } \\
\text { wall thickness (15 AL, } 21 \\
\text { ATTR) and } 15 \text { control } \\
\text { patients. All the subjects } \\
\text { underwent }{ }^{11} \mathrm{C}-\mathrm{PiB} \text { PET } \\
\text { imaging and } \\
\text { echocardiography. }\end{array}$ \\
\hline
\end{tabular}

41 chemotherapy-naïve AL cardiac amyloidosis patients were enrolled. Myocardial uptake of ${ }^{11} \mathrm{C}-\mathrm{PiB}$ on PET was compared with endomyocardial biopsy for quantification of amyloid deposit.
Results

High diagnostic accuracy of both visual inspection and semi-quantitative methods of

${ }^{11} \mathrm{C}-\mathrm{PiB}$ PET imaging to distinguish cardiac amyloidosis from controls. The uptake of ${ }^{11} \mathrm{C}-\mathrm{PiB}$ was significantly higher in AL cardiac amyloidosis than ATTR cardiac amyloidosis.

The degree of myocardial ${ }^{11} \mathrm{C}-\mathrm{PiB}$ uptake is significantly higher in patients with cardiac amyloidosis and higher degrees of uptake was associated with lowest survival from death, heart transplantation and acute decompensated heart failure.

Patients with AL amyloidosis have higher mean SUV,

biopsy-proven diagnoses of cardiac amyloidosis (20 AL amyloidosis, 20 ATTR amyloidosis) and 20 patients with non-cardiac amyloidosis pathology. heart-to-background uptake ratio, and molecular volume than ATTR amyloidosis and patients with non-cardiac amyloidosis.

$\mathrm{TBR}_{\text {mean }}$ values are higher in ATTR amyloidosis than controls and those with $\mathrm{AL}$ amyloidosis. A TBR mean threshold $>1.14$ in areas of late gadolinium enhancement has 100\% sensitivity and $100 \%$ specificity for ATTR amyloidosis compared to AL amyloidosis.

Visual assessment of ${ }^{18}$ F-sodium fluoride PET/CT had a sensitivity of $25 \%$ for ATTR cardiac amyloidosis when compared with $100 \%$ sensitivity in

${ }^{99 \mathrm{~m}}$ Tc-PYP-SPECT/CT.

\footnotetext{
${ }^{99 \mathrm{~m}} \mathrm{Tc}-\mathrm{DPD}:{ }^{99 \mathrm{~m}} \mathrm{Tc}-3,3-$ diphosphono-1,2-propanodicarboxylic acid; ${ }^{99 \mathrm{~m}} \mathrm{Tc}-\mathrm{PYP}:{ }^{99 \mathrm{~m}} \mathrm{Tc}-$ pyrophosphate; ${ }^{11} \mathrm{C}-\mathrm{PiB}:{ }^{11} \mathrm{C}-\mathrm{Pittsburgh}$ compound B.
}

\section{Positron Emission Tomography (PET)}

Positron emission tomography (PET) scanning is another imaging modality which can help diagnose cardiac amyloidosis [63]. PET imaging offers higher spatial resolution secondary to the decay of positrons and more accurate quantification of amyloid burden by using direct amyloid-binding radioactive tracers [64]. ${ }^{11} \mathrm{C}-\mathrm{Pittsburgh} \mathrm{B}\left({ }^{11} \mathrm{C}-\mathrm{PiB}\right)$ and ${ }^{18} \mathrm{~F}$-labelled agents (such as ${ }^{18} \mathrm{~F}$-florbetapir and ${ }^{18} \mathrm{~F}$-florbetaben) are the two most common 
classes of radioactive tracers used for this purpose [65]. The tracers were originally developed to bind beta amyloid in the brain of patients with Alzheimer disease but it was reported later that they might have utility in diagnosing cardiac amyloidosis as well [66]. Higher cardiac uptake of both ${ }^{11} \mathrm{C}-\mathrm{PiB}$ and ${ }^{18} \mathrm{~F}$-labelled agents was constantly observed in both AL cardiac amyloidosis and ATTR cardiac amyloidosis, compared to controls in pilot studies [29,60,67-70]. Additionally, the radiotracer activities of both ${ }^{11} \mathrm{C}-\mathrm{PiB}$ and ${ }^{18} \mathrm{~F}$-labelled agents have been found to be higher in AL cardiac amyloidosis than ATTR amyloidosis. A meta-analysis which combined the results of three pilot PET studies demonstrated that AL amyloidosis has significantly higher radiotracer activities than ATTR amyloidosis and thus PET imaging carries the potential to differentiate between AL and ATTR amyloidosis [71]. Overall, PET imaging for the diagnosis of cardiac amyloidosis is still in the early stages but future development of this technique is anticipated.

\section{7. ${ }^{11}$ C-Pittsburgh Compound B PET Imaging}

${ }^{11} \mathrm{C}$-Pittsburgh compound $\mathrm{B}\left({ }^{11} \mathrm{C}-\mathrm{PiB}\right)$ PET imaging is a well-established technique for detecting $\beta$-amyloid in Alzheimer disease [72]. PiB, thioflavin-T, is an amyloid binding dye, and is theoretically able to bind to amyloid fibrils of any type, including amyloid fibrils in the myocardium [73]. A Swedish study included 10 patients with systemic amyloidosis (7 AL, 2 hereditary ATTR, 1 wild-type ATTR) and cardiac involvement, and the results showed increased myocardial ${ }^{11} \mathrm{C}-\mathrm{PiB}$ uptake in all the patients $15-25 \mathrm{~min}$ after injection of ${ }^{11} \mathrm{C}$-PiB. On the other hand, increased uptake was not seen in the five patients of the control group [29]. A Korean prospective study, which included 22 amyloidosis patients (15 with and 7 without cardiac involvement) and 10 normal controls, calculated the SUV and found significantly higher values in patients with cardiac amyloidosis than the control group (median 3.9 (range 1.7 to 19.9) vs. 1.0 (range 0.8 to 1.2), $p<0.001$ ) [67].

${ }^{11} \mathrm{C}-\mathrm{PiB} \mathrm{PET}$ imaging shows promise for identifying specific types of cardiac amyloidosis, especially for the AL subtype. A dual-center study showed that ${ }^{11} \mathrm{C}-\mathrm{PiB}$ PET imaging had $100 \%$ diagnostic accuracy of AL amyloidosis and that the uptake was significantly higher in AL cardiac amyloidosis compared to ATTR cardiac amyloidosis [58]. Researchers from Korea compared ${ }^{11} \mathrm{C}-\mathrm{PiB}$ PET imaging with endomyocardial biopsy in patients with chemotherapy-naive AL cardiac amyloidosis and they found that the degree of the ${ }^{11} \mathrm{C}-\mathrm{PiB}$ uptake on PET image was significantly higher in patients with cardiac amyloidosis and it corresponded well with the extent of amyloid deposition on the biopsy specimens. Patients with higher ${ }^{11} \mathrm{C}-\mathrm{PiB}$ uptake had high risks of composite adverse clinical outcomes including death, requiring heart transplantation and acute decompensated heart failure [59].

A study conducted in Japan revealed that ${ }^{99 \mathrm{~m}} \mathrm{Tc}-\mathrm{PYP}$ scintigraphy and ${ }^{11} \mathrm{C}-\mathrm{PiB}$ PET imaging can complement each other. In this study, the combination of positive ${ }^{11} \mathrm{C}$-PiB PET and negative ${ }^{99 \mathrm{~m}}$ Tc-PYP was observed in all AL cardiac amyloidosis and early onset V30M hereditary ATTR cardiac amyloidosis, while the combination of positive ${ }^{99 \mathrm{~m}} \mathrm{Tc}-\mathrm{PYP}$ and negative ${ }^{11} \mathrm{C}-\mathrm{PiB}$ PET was consistent in all wild-type ATTR cardiac amyloidosis, as well as the late-onset V30M and non-V30M hereditary ATTR cardiac amyloidosis [57]. However, ${ }^{11} \mathrm{C}-\mathrm{PiB}$ PET imaging is limited by its short half-life of $20 \mathrm{~min}$ and the requirement of an onsite cyclotron for its production [74].

\section{8. ${ }^{18}$ F-Labelled Agents PET Imaging}

${ }^{18} \mathrm{~F}$-labelled PET imaging is another promising imaging technique utilizing fluoride labelled radiotracers, primarily ${ }^{18} \mathrm{~F}$-florbetapir and ${ }^{18} \mathrm{~F}$-florbetaben. ${ }^{18} \mathrm{~F}$-florbetapir and ${ }^{18} \mathrm{~F}$-florbetaben are both FDA-approved radioactive tracers for Alzheimer's disease with half-lives more than $100 \mathrm{~min}$, which is a potential advantage over ${ }^{11} \mathrm{C}$-PiB PET for use in clinical practice. [75,76]. A pilot study in 2014 which enrolled 14 subjects (9 subjects with definite cardiac amyloidosis and 5 control subjects without amyloidosis) found that myocardial retention of ${ }^{18} \mathrm{~F}$-florbetapir was higher in amyloid subjects, especially in patients with AL cardiac amyloidosis [77]. An autoradiography study using myocardial autopsy sections yielded similar results, showing that ${ }^{18} \mathrm{~F}$-florbetapir uptake was higher in amyloid 
samples versus controls but also found higher uptake in the AL groups compared to the ATTR samples [78]. Another pilot study in 2016 indicated that ${ }^{18} \mathrm{~F}-$ florbetaben PET imaging can accurately diagnose and differentiate between cardiac amyloidosis and hypertensive heart disease [69]. The percentage of myocardial ${ }^{18} \mathrm{~F}$-florbetaben retention was found to be an independent determinant of myocardial dysfunction in cardiac amyloidosis [69]. A pilot study in 2019 involving 22 subjects ( 5 proven and 17 with clinical suspicion of cardiac amyloidosis) revealed that ${ }^{18} \mathrm{~F}$-florbetaben-PET could further distinguish between the underlying amyloid types with higher retention in patients with AL amyloidosis than ATTR amyloidosis [79]. A recently published prospective study showed that delayed ${ }^{18} \mathrm{~F}$ florbetaben cardiac uptake may distinguish AL cardiac amyloidosis from ATTR amyloidosis given higher mean SUV in patients with AL amyloidosis which was sustained over the whole acquisition period [60]. In addition, amyloid-directed PET can be used to assess therapy response. It has been shown that amyloid burden on PET after treatment with antiinflammatory (AA), anti-myeloma (AL) and TTR-stabilizing (ATTR) therapies correlated well with changes in performance status and serological markers [79]. A series of most recent studies for ${ }^{11} \mathrm{C}-\mathrm{PiB}$ and ${ }^{18} \mathrm{~F}$-labelled agents PET imaging can be found in Table 1.

Researchers have combined fluoride PET imaging with MRI in patients with cardiac amyloidosis to improve diagnostic accuracy of ATTR amyloidosis [61]. However, while PET imaging can distinguish between cardiac amyloidosis and controls, particularly when using quantitative analysis, it seems to be less sensitive when diagnosing cardiac amyloidosis than the more established nuclear medicine studies with ${ }^{99 \mathrm{~m}} \mathrm{Tc}-\mathrm{PYP}$ or ${ }^{99 \mathrm{~m}} \mathrm{Tc}-\mathrm{DPD}[62,80]$. The comparison between cardiac scintigraphy and PET imaging is summarized in Table 2.

Table 2. Comparison between the four most-studied nuclear imaging techniques for cardiac amyloidosis.

\begin{tabular}{|c|c|c|c|c|c|c|}
\hline $\begin{array}{l}\text { Imaging } \\
\text { Technique }\end{array}$ & $\begin{array}{l}\text { Radiotracer } \\
\text { Component }\end{array}$ & $\begin{array}{l}\text { Radiotracer } \\
\text { Analog }\end{array}$ & $\begin{array}{l}\text { Radiotracers } \\
\text { Original } \\
\text { Application }\end{array}$ & $\begin{array}{l}\text { Amyloidosis } \\
\text { Type }\end{array}$ & Advantage & Disadvantage \\
\hline $\begin{array}{l}99 \mathrm{~m} \text { Tc-DPD } \\
\text { Scintigraphy }\end{array}$ & $\begin{array}{c}\text { 99m Tc-3,3-diphosphono- } \\
\text { 1,2- } \\
\text { propanodicarboxylic } \\
\text { acid }\end{array}$ & \multirow[t]{2}{*}{ Phosphate } & \multirow[t]{2}{*}{$\begin{array}{c}\text { Bone } \\
\text { scintigraphy }\end{array}$} & \multirow{2}{*}{$\begin{array}{l}\text { ATTR } \\
\text { amyloidosis } \\
>>\text { AL } \\
\text { amyloidosis. }\end{array}$} & \multirow{2}{*}{$\begin{array}{l}\text { High diagnostic accuracy } \\
\text { for ATTR when combined } \\
\text { with SPECT and the } \\
\text { absence of a monoclonal } \\
\text { protein in serum or urine. }\end{array}$} & \multirow{2}{*}{$\begin{array}{l}\text { Limited on } \\
\text { accurate } \\
\text { quantification } \\
\text { of amyloid } \\
\text { burden. }\end{array}$} \\
\hline $\begin{array}{l}99 \mathrm{~m} \text { Tc-PYP } \\
\text { Scintigraphy }\end{array}$ & ${ }^{99 \mathrm{~m}}$ Tc-Pyrophosphate & & & & & \\
\hline $\begin{array}{l}{ }^{11} \mathrm{C} \text {-PiB PET } \\
\text { imaging }\end{array}$ & $\begin{array}{l}\mathrm{N}-\text { methyl- }\left[{ }^{11} \mathrm{C}\right] 2-\left(4^{\prime}-\right. \\
\text { methylaminophenyl)-6- } \\
\text { hydroxybenzothiazole }\end{array}$ & Thioflavin-T & \multirow{2}{*}{$\begin{array}{c}\text { Brain imaging } \\
\text { in Alzheimer } \\
\text { dementia. }\end{array}$} & \multirow{2}{*}{$\begin{array}{c}\text { AL } \\
\text { amyloidosis > } \\
\text { ATTR } \\
\text { amyloidosis. }\end{array}$} & $\begin{array}{l}\text { Detect both AL and ATTR } \\
\text { amyloidosis, ability to } \\
\text { detect early disease, short } \\
\text { study session. Can } \\
\text { complement }{ }^{99 \mathrm{~m}} \text { Tc-PYP } \\
\text { Scintigraphy. }\end{array}$ & $\begin{array}{l}\text { Requirement of } \\
\text { onsite cyclotron } \\
\text { for generation; } \\
\text { high synthesis } \\
\text { cost with } \\
\text { 20-min half-life. }\end{array}$ \\
\hline $\begin{array}{l}{ }^{18} \text { F-labelled } \\
\text { agents PET } \\
\text { imaging }\end{array}$ & $\begin{array}{c}{ }^{18} \text { F-florbetapir, } \\
{ }^{18} \text { F-florbetaben }{ }^{18} \text { F-NaF }\end{array}$ & Stilbene & & & $\begin{array}{l}\text { Can diagnose both AL } \\
\text { amyloidosis and ATTR } \\
\text { amyloidosis. Allows for } \\
\text { early detection of cardiac } \\
\text { amyloidosis, aid in } \\
\text { therapy response } \\
\text { assessment. }\end{array}$ & $\begin{array}{l}\text { Lack of } \\
\text { large-sized } \\
\text { studies to } \\
\text { confirm its } \\
\text { efficacy. }\end{array}$ \\
\hline
\end{tabular}

${ }^{99 \mathrm{~m}} \mathrm{Tc}-\mathrm{DPD}:{ }^{99 \mathrm{~m}} \mathrm{Tc}-3,3-$ diphosphono-1,2-propanodicarboxylic acid; ${ }^{99 \mathrm{~m}} \mathrm{Tc}-\mathrm{PYP}:{ }^{99 \mathrm{~m}} \mathrm{Tc}-$ pyrophosphate; ${ }^{11} \mathrm{C}-\mathrm{PiB}:{ }^{11} \mathrm{C}-\mathrm{Pittsburgh}$ compound B.

Our review highlights the importance of nuclear imaging for the diagnosis of cardiac amyloidosis with most updated clinical evidence and covers the most common radiotracers in this field. We not only elaborate on cardiac scintigraphy which is the more established nuclear imaging modality for cardiac amyloidosis, but also include the most recent evidence regarding PET imaging. However, we do acknowledge that other radiotracers, for example ${ }^{99 \mathrm{~m}} \mathrm{Tc}-\mathrm{HMDP}$, are present and may play a role in the diagnosis of cardiac amyloidosis. In addition, we are unable to find large-sized clinical studies to compare between those radiotracers mentioned in this review. 


\section{Conclusions}

Cardiac scintigraphy with SPECT is the current standard of care for diagnosing patients with ATTR cardiac amyloidosis. However, PET imaging is another promising, noninvasive option for the diagnosis of cardiac amyloidosis and may help distinguish between AL amyloidosis and ATTR amyloidosis. The potential benefit of PET-based radiotracers includes better sensitivity for AL cardiac amyloidosis diagnosis and assessment of response to treatment. Future studies are anticipated.

Funding: This research received no external funding.

Institutional Review Board Statement: Not applicable.

Informed Consent Statement: Not applicable.

Data Availability Statement: Not applicable.

Conflicts of Interest: James M. Tauras served as site principal investigator for several cardiac amyloidosis clinical trials and has received honoraria from Eidos Therapeutics, Inc., and Pfizer. There are no other disclosures relevant to this article.

\section{References}

1. Alexander, K.M.; Orav, J.; Singh, A.; Jacob, S.A.; Menon, A.; Padera, R.F.; Kijewski, M.F.; Liao, R.; Di Carli, M.F.; Laubach, J.P.; et al. Geographic Disparities in Reported US Amyloidosis Mortality From 1979 to 2015: Potential Underdetection of Cardiac Amyloidosis. JAMA Cardiol. 2018, 3, 865-870. [CrossRef] [PubMed]

2. Blancas-Mejía, L.M.; Ramirez-Alvarado, M. Systemic Amyloidoses. Annu. Rev. Biochem. 2013, 82, 745-774. [CrossRef] [PubMed]

3. Ravichandran, S.; Lachmann, H.J.; Wechalekar, A.D. Epidemiologic and Survival Trends in Amyloidosis, 1987-2019. N. Engl. J. Med. 2020, 382, 1567-1568. [CrossRef] [PubMed]

4. Pinney, J.H.; Smith, C.J.; Taube, J.B.; Lachmann, H.J.; Venner, C.P.; Gibbs, S.D.J.; Dungu, J.; Banypersad, S.M.; Wechalekar, A.D.; Whelan, C.J.; et al. Systemic Amyloidosis in England: An epidemiological study. Br. J. Haematol. 2013, 161, 525-532. [CrossRef]

5. Seo, S.R.; Jang, S.Y.; Lee, G.Y.; Choi, B.; Chun, H.; Cho, E.J.; Cho, S.-I. Prevalence of Amyloidosis in Korea. Orphanet J. Rare Dis. 2017, 12, 1-5. [CrossRef]

6. Nienhuis, H.L.; Bijzet, J.; Hazenberg, B.P. The Prevalence and Management of Systemic Amyloidosis in Western Countries. Kidney Dis. 2016, 2, 10-19. [CrossRef] [PubMed]

7. Tanskanen, M.; Peuralinna, T.; Polvikoski, T.; Notkola, I.; Sulkava, R.; Hardy, J.; Singleton, A.; Kiuru-Enari, S.; Paetau, A.; Tienari, P.J.; et al. Senile systemic amyloidosis affects $25 \%$ of the very aged and associates with genetic variation in alpha2-macroglobulin and tau: A population-based autopsy study. Ann. Med. 2008, 40, 232-239. [CrossRef]

8. Cornwell, G.G., III; Sletten, K.; Johansson, B.; Westermark, P. Evidence that the amyloid fibril protein in senile systemic amyloidosis is derived from normal prealbumin. Biochem. Biophys. Res. Commun. 1988, 154, 648-653. [CrossRef]

9. Ueda, M.; Horibata, Y.; Shono, M.; Misumi, Y.; Oshima, T.; Su, Y.; Tasaki, M.; Shinriki, S.; Kawahara, S.; Jono, H.; et al. Clinicopathological features of senile systemic amyloidosis: An ante- and post-mortem study. Mod. Pathol. 2011, 24, 1533-1544. [CrossRef]

10. Shah, K.B.; Inoue, Y.; Mehra, M.R. Amyloidosis and the heart: A comprehensive review. Arch. Intern. Med. 2006, 166, 1805-1813. [CrossRef]

11. Gilstrap, L.G.; Dominici, F.; Wang, Y.; El-Sady, M.S.; Singh, A.; Di Carli, M.F.; Falk, R.H.; Dorbala, S. Epidemiology of Cardiac Amyloidosis-Associated Heart Failure Hospitalizations Among Fee-for-Service Medicare Beneficiaries in the United States. Circ. Heart Fail. 2019, 12, e005407. [CrossRef]

12. Cuscaden, C.; Ramsay, S.C.; Prasad, S.; Goodwin, B.; Smith, J. Estimation of prevalence of transthyretin (ATTR) cardiac amyloidosis in an Australian subpopulation using bone scans with echocardiography and clinical correlation. J. Nucl. Cardiol. 2020, 1-12. [CrossRef]

13. Wechalekar, K.; Wechalekar, A.D. Wild-type transthyretin cardiac amyloidosis: When is a rare disease no longer a rare disease? J. Nucl. Cardiol. 2020, 1-3. [CrossRef]

14. Sanchorawala, V. Light-Chain (AL) Amyloidosis: Diagnosis and Treatment. Clin. J. Am. Soc. Nephrol. 2006, 1, 1331-1341. [CrossRef]

15. Yamamoto, H.; Yokochi, T. Transthyretin cardiac amyloidosis: An update on diagnosis and treatment. ESC Heart Fail. 2019, 6, 1128-1139. [CrossRef] [PubMed]

16. Halatchev, I.G.; Zheng, J.; Ou, J. Wild-type transthyretin cardiac amyloidosis (ATTRwt-CA), previously known as senile cardiac amyloidosis: Clinical presentation, diagnosis, management and emerging therapies. J. Thorac. Dis. 2018, 10, 2034-2045. [CrossRef] [PubMed]

17. Puig-Carrion, G.D.; Reyentovich, A.; Katz, S.D. Diagnosis and treatment of heart failure in hereditary transthyretin amyloidosis. Clin. Auton. Res. 2019, 29 (Suppl. 1), 45-53. [CrossRef] 
18. Macedo, A.V.S.; Schwartzmann, P.V.; De Gusmão, B.M.; De Melo, M.D.T.; Coelho-Filho, O.R. Advances in the Treatment of Cardiac Amyloidosis. Curr. Treat. Options Oncol. 2020, 21, 1-18. [CrossRef]

19. Palladini, G.; Milani, P.; Merlini, G. Management of AL amyloidosis in 2020. Blood 2020, 136, 2620-2627. [CrossRef]

20. Maurer, M.S.; Schwartz, J.H.; Gundapaneni, B.; Elliott, P.M.; Merlini, G.; Waddington-Cruz, M.; Kristen, A.V.; Grogan, M.; Witteles, R.; Damy, T.; et al. Tafamidis Treatment for Patients with Transthyretin Amyloid Cardiomyopathy. N. Engl. J. Med. 2018, 379, 1007-1016. [CrossRef] [PubMed]

21. Pellikka, P.A.; Holmes, D.R.; Edwards, W.D.; Nishimura, R.A.; Tajik, A.J.; Kyle, R.A. Endomyocardial biopsy in 30 patients with primary amyloidosis and suspected cardiac involvement. Arch. Intern. Med. 1988, 148, 662-666. [CrossRef]

22. Wisniowski, B.; Wechalekar, A. Confirming the Diagnosis of Amyloidosis. Acta Haematol. 2020, 143, 312-321. [CrossRef]

23. Yilmaz, A.; Kindermann, I.; Kindermann, M.; Mahfoud, F.; Ukena, C.; Athanasiadis, A.; Hill, S.; Mahrholdt, H.; Voehringer, M.; Schieber, M.; et al. Comparative evaluation of left and right ventricular endomyocardial biopsy: Differences in complication rate and diagnostic performance. Circulation 2010, 122, 900-909. [CrossRef]

24. From, A.M.; Maleszewski, J.J.; Rihal, C.S. Current Status of Endomyocardial Biopsy. Mayo Clin. Proc. 2011, 86, 1095-1102. [CrossRef] [PubMed]

25. Wang, T.K.M.; Hassan, O.K.A.; Jaber, W.; Xu, B. Multi-modality imaging of cardiac amyloidosis: Contemporary update. World J. Radiol. 2020, 12, 87-100. [CrossRef]

26. Dorbala, S.; Ando, Y.; Bokhari, S.; Dispenzieri, A.; Falk, R.H.; Ferrari, V.; Fontana, M.; Gheysens, O.; Gillmore, J.D.; Glaudemans, A.W.; et al. ASNC/AHA/ASE/EANM/HFSA/ISA/SCMR/SNMMI Expert Consensus Recommendations for Multimodality Imaging in Cardiac Amyloidosis: Part 1 of 2-Evidence Base and Standardized Methods of Imaging. J. Card. Fail. 2019, 25, e1-e39. [CrossRef] [PubMed]

27. Dorbala, S.; Ando, Y.; Bokhari, S.; Dispenzieri, A.; Falk, R.H.; Ferrari, V.; Fontana, M.; Gheysens, O.; Gillmore, J.D.; Glaudemans, A.W.; et al. ASNC/AHA/ASE/EANM/HFSA/ISA/SCMR/SNMMI Expert Consensus Recommendations for Multimodality Imaging in Cardiac Amyloidosis: Part 2 of 2-Diagnostic Criteria and Appropriate Utilization. J. Card. Fail. 2019, 25, 854-865. [CrossRef] [PubMed]

28. Kinahan, P.E.; Fletcher, J.W. Positron Emission Tomography-Computed Tomography Standardized Uptake Values in Clinical Practice and Assessing Response to Therapy. Semin. Ultrasound CT MRI 2010, 31, 496-505. [CrossRef]

29. Antoni, G.; Lubberink, M.; Estrada, S.; Axelsson, J.; Carlson, K.; Lindsjö, L.; Kero, T.; Långström, B.R.; Granstam, S.-O.; Rosengren, S.; et al. In Vivo Visualization of Amyloid Deposits in the Heart with 11C-PIB and PET. J. Nucl. Med. 2013, 54, 213-220. [CrossRef]

30. Cuddy, S.A.M.; Bravo, P.E.; Falk, R.H.; El-Sady, S.; Kijewski, M.F.; Park, M.; Ruberg, F.L.; Sanchorawala, V.; Landau, H.; Yee, A.J.; et al. Improved Quantification of Cardiac Amyloid Burden in Systemic Light Chain Amyloidosis: Redefining Early Disease? JACC Cardiovasc. Imaging 2020, 13, 1325-1336. [CrossRef] [PubMed]

31. Kero, T.; Sörensen, J.; Antoni, G.; Wilking, H.; Carlson, K.; Vedin, O.; Rosengren, S.; Wikström, G.; Lubberink, M. Quantification of 11C-PIB kinetics in cardiac amyloidosis. J. Nucl. Cardiol. 2020, 27, 774-784. [CrossRef]

32. Kula, R.; Engel, W.; Line, B. Scanning for soft-tissue amyloid. Lancet 1977, 309, 92-93. [CrossRef]

33. Gillmore, J.D.; Maurer, M.S.; Falk, R.H.; Merlini, G.; Damy, T.; Dispenzieri, A.; Wechalekar, A.D.; Berk, J.L.; Quarta, C.C.; Grogan, M.; et al. Nonbiopsy Diagnosis of Cardiac Transthyretin Amyloidosis. Circulation 2016, 133, 2404-2412. [CrossRef]

34. Treglia, G.; Glaudemans, A.W.J.M.; Bertagna, F.; Hazenberg, B.P.C.; Erba, P.A.; Giubbini, R.; Ceriani, L.; Prior, J.O.; Giovanella, L.; Slart, R.H.J.A. Diagnostic accuracy of bone scintigraphy in the assessment of cardiac transthyretin-related amyloidosis: A bivariate meta-analysis. Eur. J. Nucl. Med. Mol. Imaging 2018, 45, 1945-1955. [CrossRef] [PubMed]

35. Bokhari, S.; Castaño, A.; Pozniakoff, T.; Deslisle, S.; Latif, F.; Maurer, M.S. 99m Tc-Pyrophosphate Scintigraphy for Differentiating Light-Chain Cardiac Amyloidosis From the Transthyretin-Related Familial and Senile Cardiac Amyloidoses. Circ. Cardiovasc. Imaging 2013, 6, 195-201. [CrossRef] [PubMed]

36. Garcia-Pavia, P.; Rapezzi, C.; Adler, Y.; Arad, M.; Basso, C.; Brucato, A.; Burazor, I.; Caforio, A.L.P.; Damy, T.; Eriksson, U.; et al. Diagnosis and treatment of cardiac amyloidosis: A position statement of the ESC Working Group on Myocardial and Pericardial Diseases. Eur. Heart J. 2021, 42, 1554-1568. [CrossRef] [PubMed]

37. Grigoratos, C.; Aimo, A.; Rapezzi, C.; Genovesi, D.; Barison, A.; Aquaro, G.D.; Vergaro, G.; Pucci, A.; Passino, C.; Marzullo, P.; et al. Diphosphonate single-photon emission computed tomography in cardiac transthyretin amyloidosis. Int. J. Cardiol. 2020, 307, 187-192. [CrossRef]

38. Perugini, E.; Guidalotti, P.L.; Salvi, F.; Cooke, R.M.T.; Pettinato, C.; Riva, L.; Leone, O.; Farsad, M.; Ciliberti, P.; Bacchi-Reggiani, L.; et al. Noninvasive etiologic diagnosis of cardiac amyloidosis using 99mTc-3,3-diphosphono-1,2-propanodicarboxylic acid scintigraphy. J. Am. Coll. Cardiol. 2005, 46, 1076-1084. [CrossRef]

39. Caobelli, F.; Braun, M.; Haaf, P.; Wild, D.; Zellweger, M.J. Quantitative 99mTc-DPD SPECT/CT in patients with suspected ATTR cardiac amyloidosis: Feasibility and correlation with visual scores. J. Nucl. Cardiol. 2020, 27, 1456-1463. [CrossRef]

40. Hutt, D.F.; Fontana, M.; Burniston, M.; Quigley, A.; Petrie, A.; Ross, J.C.; Page, J.; Martinez-Naharro, A.; Wechalekar, A.D.; Lachmann, H.J.; et al. Prognostic utility of the Perugini grading of 99mTc-DPD scintigraphy in transthyretin (ATTR) amyloidosis and its relationship with skeletal muscle and soft tissue amyloid. Eur. Heart J. Cardiovasc. Imaging 2017, 18, 1344-1350. [CrossRef] [PubMed] 
41. Gallini, C.; Tutino, F.; Martone, R.; Ciaccio, A.; Costanzo, E.N.; Taborchi, G.; Morini, S.; Bartolini, S.; Farsetti, S.; di Mario, C.; et al. Semi-quantitative indices of cardiac uptake in patients with suspected cardiac amyloidosis undergoing 99mTc-HMDP scintigraphy. J. Nucl. Cardiol. 2019. [CrossRef]

42. Moore, P.T.; Burrage, M.K.; MacKenzie, E.; Law, W.P.; Korczyk, D.; Mollee, P. The Utility of 99m Tc-DPD Scintigraphy in the Diagnosis of Cardiac Amyloidosis: An Australian Experience. Heart Lung Circ. 2017, 26, 1183-1190. [CrossRef] [PubMed]

43. Rapezzi, C.; Quarta, C.C.; Guidalotti, P.L.; Pettinato, C.; Fanti, S.; Leone, O.; Ferlini, A.; Longhi, S.; Lorenzini, M.; Reggiani, L.B.; et al. Role of 99mTc-DPD Scintigraphy in Diagnosis and Prognosis of Hereditary Transthyretin-Related Cardiac Amyloidosis. JACC Cardiovasc. Imaging 2011, 4, 659-670. [CrossRef]

44. Sachchithanantham, S.; Hutt, D.F.; Hawkins, P.; Wechalekar, A.D.; Quigley, A.-M. Role of 99m Tc-DPD scintigraphy in imaging extra-cardiac light chain (AL) amyloidosis. Br. J. Haematol. 2018, 183, 506-509. [CrossRef]

45. Manrique, A.; Dudoignon, D.; Brun, S.; N’Ganoa, C.; Cassol, E.; Legallois, D.; Lavie-Badie, Y.; Agostini, D.; Lairez, O. Quantification of myocardial 99mTc-labeled bisphosphonate uptake with cadmium zinc telluride camera in patients with transthyretinrelated cardiac amyloidosis. EJNMMI Res. 2019, 9, 1-7. [CrossRef] [PubMed]

46. Scully, P.R.; Morris, E.; Patel, K.P.; Treibel, T.A.; Burniston, M.; Klotz, E.; Newton, J.D.; Sabharwal, N.; Kelion, A.; Manisty, C.; et al. DPD Quantification in Cardiac Amyloidosis: A Novel Imaging Biomarker. JACC Cardiovasc. Imaging 2020, 13, 1353-1363. [CrossRef] [PubMed]

47. Wollenweber, T.; Rettl, R.; Kretschmer-Chott, E.; Rasul, S.; Kulterer, O.; Rainer, E.; Raidl, M.; Schaffarich, M.P.; Matschitsch, S.; Stadler, M.; et al. In Vivo Quantification of Myocardial Amyloid Deposits in Patients with Suspected Transthyretin-Related Amyloidosis (ATTR). J. Clin. Med. 2020, 9, 3446. [CrossRef]

48. Löfbacka, V.; Axelsson, J.; Pilebro, B.; Suhr, O.B.; Lindqvist, P.; Sundström, T. Cardiac transthyretin amyloidosis 99mTc-DPD SPECT correlates with strain echocardiography and biomarkers. Eur. J. Nucl. Med. Mol. Imaging 2021, 48, 1822-1832. [CrossRef]

49. Ruberg, F.L.; Miller, E.J. Nuclear tracers for transthyretin cardiac amyloidosis: Time to bone up? Circ. Cardiovasc. Imaging 2013, 6, 162-164. [CrossRef]

50. Castano, A.; Bokhari, S.; Brannagan, T.H.; Wynn, J.; Maurer, M.S. Technetium pyrophosphate myocardial uptake and peripheral neuropathy in a rare variant of familial transthyretin (TTR) amyloidosis (Ser23Asn): A case report and literature review. Amyloid 2012, 19, 41-46. [CrossRef] [PubMed]

51. Bokhari, S.; Shahzad, R.; Castaño, A.; Maurer, M.S. Nuclear imaging modalities for cardiac amyloidosis. J. Nucl. Cardiol. 2014, 21, 175-184. [CrossRef]

52. Masri, A.; Bukhari, S.; Ahmad, S.; Nieves, R.; Eisele, Y.S.; Follansbee, W.; Brownell, A.; Wong, T.C.; Schelbert, E.; Soman, P. Efficient 1-Hour Technetium-99 m Pyrophosphate Imaging Protocol for the Diagnosis of Transthyretin Cardiac Amyloidosis. Circ. Cardiovasc. Imaging 2020, 13, e010249. [CrossRef]

53. Castano, A.; Haq, M.; Narotsky, D.L.; Goldsmith, J.; Weinberg, R.L.; Morgenstern, R.; Pozniakoff, T.; Ruberg, F.L.; Miller, E.J.; Berk, J.L.; et al. Multicenter Study of Planar Technetium 99m Pyrophosphate Cardiac Imaging: Predicting Survival for Patients with ATTR Cardiac Amyloidosis. JAMA Cardiol. 2016, 1, 880-889. [CrossRef] [PubMed]

54. Asif, T.; Gomez, J.; Singh, V.; Doukky, R.; Nedeltcheva, A.; Malhotra, S. Comparison of planar with tomographic pyrophosphate scintigraphy for transthyretin cardiac amyloidosis: Perils and pitfalls. J. Nucl. Cardiol. 2021, 28, 104-111. [CrossRef]

55. Tamarappoo, B.; Otaki, Y.; Manabe, O.; Hyun, M.; Cantu, S.; Arnson, Y.; Gransar, H.; Hayes, S.W.; Friedman, J.D.; Thomson, L.; et al. Simultaneous Tc-99m PYP/Tl-201 dual-isotope SPECT myocardial imaging in patients with suspected cardiac amyloidosis. J. Nucl. Cardiol. 2019, 27, 28-37. [CrossRef] [PubMed]

56. Ochi, Y.; Kubo, T.; Nakashima, Y.; Baba, Y.; Hirota, T.; Yamasaki, N.; Yamashita, T.; Ueda, M.; Ando, Y.; Kitaoka, H. Integrated diagnostic approach to wild-type transthyretin cardiac amyloidosis with the use of high-sensitivity cardiac troponin T measurement and 99mTc-pyrophosphate scintigraphy. J. Cardiol. 2020, 75, 12-19. [CrossRef] [PubMed]

57. Takasone, K.; Katoh, N.; Takahashi, Y.; Abe, R.; Ezawa, N.; Yoshinaga, T.; Yanagisawa, S.; Yazaki, M.; Oguchi, K.; Koyama, J.; et al. Non-invasive detection and differentiation of cardiac amyloidosis using 99mTc-pyrophosphate scintigraphy and 11C-Pittsburgh compound B PET imaging. Amyloid 2020, 27, 266-274. [CrossRef]

58. Rosengren, S.; Clemmensen, T.S.; Tolbod, L.P.; Granstam, S.-O.; Eiskjær, H.; Wikström, G.; Vedin, O.; Kero, T.; Lubberink, M.; Harms, H.J.; et al. Diagnostic Accuracy of [11C]PIB Positron Emission Tomography for Detection of Cardiac Amyloidosis. JACC Cardiovasc. Imaging 2020, 13, 1337-1347. [CrossRef]

59. Lee, S.-P.; Suh, H.-Y.; Park, S.; Oh, S.; Kwak, S.-G.; Kim, H.-M.; Koh, Y.; Park, J.-B.; Kim, H.-K.; Cho, H.-J.; et al. Pittsburgh B Compound Positron Emission Tomography in Patients With AL Cardiac Amyloidosis. J. Am. Coll. Cardiol. 2020, 75, 380-390. [CrossRef] [PubMed]

60. Genovesi, D.; Vergaro, G.; Giorgetti, A.; Marzullo, P.; Scipioni, M.; Santarelli, M.F.; Pucci, A.; Buda, G.; Volpi, E.; Emdin, M. [18F]-Florbetaben PET/CT for Differential Diagnosis Among Cardiac Immunoglobulin Light Chain, Transthyretin Amyloidosis, and Mimicking Conditions. JACC Cardiovasc. Imaging 2021, 14, 246-255. [CrossRef]

61. Andrews, J.P.M.; Trivieri, M.G.; Everett, R.; Spath, N.; MacNaught, G.; Moss, A.J.; Doris, M.K.; Pawade, T.; Van Beek, E.J.R.; Lucatelli, C.; et al. 18F-fluoride PET/MR in cardiac amyloid: A comparison study with aortic stenosis and age- and sex-matched controls. J. Nucl. Cardiol. 2020, 1-9. [CrossRef] 
62. Zhang, L.X.; Martineau, P.; Finnerty, V.; Giraldeau, G.; Parent, M.; Harel, F.; Pelletier-Galarneau, M. Comparison of 18F-sodium fluoride positron emission tomography imaging and 99mTc-pyrophosphate in cardiac amyloidosis. J. Nucl. Cardiol. 2020. [CrossRef] [PubMed]

63. Shukla, A.K.; Kumar, U. Positron emission tomography: An overview. J. Med. Phys. 2006, 31, 13-21. [CrossRef]

64. Lee, J.H.; Lee, G.Y.; Kim, S.J.; Kim, K.H.; Jeon, E.-S.; Lee, K.-H.; Kim, B.-T.; Choi, J.Y. Imaging Findings and Literature Review of 18F-FDG PET/CT in Primary Systemic AL Amyloidosis. Nucl. Med. Mol. Imaging 2015, 49, 182-190. [CrossRef] [PubMed]

65. Wolk, D.A.; Zhang, Z.; Boudhar, S.; Clark, C.M.; Pontecorvo, M.J.; Arnold, S.E. Amyloid imaging in Alzheimer's disease: Comparison of florbetapir and Pittsburgh compound-B positron emission tomography. J. Neurol. Neurosurg. Psychiatry 2012, 83, 923-926. [CrossRef] [PubMed]

66. Lhommel, R.; Sempoux, C.; Ivanoiu, A.; Michaux, L.; Gerber, B. Is 18F-Flutemetamol PET/CT Able to Reveal Cardiac Amyloidosis? Clin. Nucl. Med. 2014, 39, 747-749. [CrossRef]

67. Lee, S.-P.; Lee, E.S.; Choi, H.; Im, H.-J.; Koh, Y.; Lee, M.-H.; Kwon, J.-H.; Paeng, J.C.; Kim, H.-K.; Cheon, G.J.; et al. 11C-Pittsburgh B PET Imaging in Cardiac Amyloidosis. JACC Cardiovasc. Imaging 2015, 8, 50-59. [CrossRef]

68. Dorbala, S.; Vangala, D.; Semer, J.; Strader, C.; Bruyere, J.R.; Di Carli, M.F.; Moore, S.C.; Falk, R.H. Imaging cardiac amyloidosis: A pilot study using 18F-florbetapir positron emission tomography. Eur. J. Nucl. Med. Mol. Imaging 2014, 41, 1652-1662. [CrossRef]

69. Law, W.P.; Wang, W.Y.S.; Moore, P.T.; Mollee, P.N.; Ng, A.C.T. Cardiac Amyloid Imaging with 18F-Florbetaben PET: A Pilot Study. J. Nucl. Med. 2016, 57, 1733-1739. [CrossRef]

70. Dietemann, S.; Nkoulou, R. Amyloid PET imaging in cardiac amyloidosis: A pilot study using 18F-flutemetamol positron emission tomography. Ann. Nucl. Med. 2019, 33, 624-628. [CrossRef]

71. Kim, Y.J.; Ha, S. Cardiac amyloidosis imaging with amyloid positron emission tomography: A systematic review and metaanalysis. J. Nucl. Cardiol. 2020, 27, 123-132. [CrossRef]

72. Cohen, A.D.; Rabinovici, G.D.; Mathis, C.A.; Jagust, W.J.; Klunk, W.; Ikonomovic, M.D. Using Pittsburgh Compound B for In Vivo PET Imaging of Fibrillar Amyloid-Beta. Charact. Porous Solids III 2012, 64, 27-81. [CrossRef]

73. Levine, H., III. Soluble multimeric Alzheimer beta(1-40) pre-amyloid complexes in dilute solution. Neurobiol. Aging 1995, 16, 755-764. [CrossRef]

74. Dorbala, S.; Cuddy, S.; Falk, R.H. How to Image Cardiac Amyloidosis: A Practical Approach. JACC Cardiovasc. Imaging 2020, 13, 1368-1383. [CrossRef] [PubMed]

75. Martínez, G.; Vernooij, R.W.; Padilla, P.F.; Zamora, J.; Cosp, X.B.; Flicker, L. 18F PET with florbetapir for the early diagnosis of Alzheimer's disease dementia and other dementias in people with mild cognitive impairment (MCI). Cochrane Database Syst. Rev. 2017, 11, CD012216. [CrossRef] [PubMed]

76. Martínez, G.; Vernooij, R.W.M.; Padilla, P.F.; Zamora, J.; Flicker, L.; Cosp, X.B. 18F PET with florbetaben for the early diagnosis of Alzheimer's disease dementia and other dementias in people with mild cognitive impairment (MCI). Cochrane Database Syst. Rev. 2017, 11, CD012883. [CrossRef]

77. Manwani, R.; Page, J.; Lane, T.; Burniston, M.; Skillen, A.; Lachmann, H.J.; Gillmore, J.D.; Fontana, M.; Whelan, C.; Hawkins, P.N.; et al. A pilot study demonstrating cardiac uptake with 18F-florbetapir PET in AL amyloidosis patients with cardiac involvement. Amyloid 2018, 25, 247-252. [CrossRef]

78. Park, M.-A.; Padera, R.F.; Belanger, A.; Dubey, S.; Hwang, D.H.; Veeranna, V.; Falk, R.H.; di Carli, M.F.; Dorbala, S. 18F-Florbetapir Binds Specifically to Myocardial Light Chain and Transthyretin Amyloid Deposits: Autoradiography Study. Circ. Cardiovasc. Imaging 2015, 8. [CrossRef]

79. Kircher, M.; Ihne, S.; Brumberg, J.; Morbach, C.; Knop, S.; Kortüm, K.M.; Störk, S.; Buck, A.K.; Reiter, T.; Bauer, W.R.; et al. Detection of cardiac amyloidosis with 18F-Florbetaben-PET/CT in comparison to echocardiography, cardiac MRI and DPDscintigraphy. Eur. J. Nucl. Med. Mol. Imaging 2019, 46, 1407-1416. [CrossRef]

80. Martineau, P.; Finnerty, V.; Giraldeau, G.; Authier, S.; Harel, F.; Pelletier-Galarneau, M. Examining the sensitivity of 18 F-NaF PET for the imaging of cardiac amyloidosis. J. Nucl. Cardiol. 2019. [CrossRef] 